Special Issue: Agricultural Productivity and Sustainability Improvement in Tropical Region

\title{
Characterization Properties of Extruded Analog Rice Developed from Arrowroot Starch with Addition of Seaweed and Spices
}

\author{
Damat Damat $^{1 *}$, Roy Hendroko Setyobudi², Juris Burlakovs ${ }^{3}$, Zane Vincēviča-Gaile ${ }^{4}$, \\ Devi Dwi Siskawardani ${ }^{1}$, Rista Anggriani ${ }^{1}$ and Anas Tain ${ }^{5}$
}

${ }^{1}$ Department of Food Technology, Faculty of Agriculture and Animal Science, University of Muhammadiyah Malang, Jln. Raya Tlogomas No.246, Malang 65144, Indonesia; ${ }^{2}$ Department of Agriculture Science, Postgraduate Program, University of Muhammadiyah Malang, Malang 65144, Indonesia; ${ }^{3}$ Estonian University of Life Sciences, Tartu, Estonia; Friedrich Reinhold Kreutzwaldi 1a, 51014 Tartu, Estonia; ${ }^{4}$ University of Latvia, Jelgavas Street 1, Room 302, Riga LV-1004, Latvia; ${ }^{5}$ Department of Agribusiness, Faculty of Agriculture and Animal Science, University of Mubammadiyah Malang, Malang 65144, Indonesia.

Abstract $\mid$ Analog rice is a processed rice product produced from non-rice with slightly more carbohydrates than natural rice. Arrowroot (Maranta arundinacea L) can be used as raw material in analog rice, with red seaweed (Gracilaria spp.) are added to increase the fiber content. A disadvantage of analog rice is its bland taste, which can be improved by adding spices and seaweed, expected to increase the functional value. This study aims to determine the effect of the addition of various seaweed pulp concentrations and spice formulations on the characteristics of analog rice. Various formulas of concentrated seaweed pulp ( $5 \mathrm{~g}, 10 \mathrm{~g}$, and $15 \mathrm{~g})$ and spice formulations (onion, garlic, ginger, turmeric, and lemongrass) were applied, and a Randomized Block Design with three replications was used. Subsequently, observation variables included analysis of water content, ash, carbohydrate, protein, fat, antioxidant activity, fiber content, water absorption index, color intensity, and sensory evaluation. The data were analyzed by ANOVA and continued according to Duncan's multiple range test. The results showed that all formulas of analog rice produced from arrowroot starch, with the addition of seaweed pulp and spices, fulfill the chemical and physical properties of paddy rice requirements according to Indonesian National Standard No. 6128-2008. With an increasing concentration of the seaweed pulp, the food fiber, and the resistant starch content increased. The antioxidant activity of the analog rice also increased with the addition of spices, which provided a more attractive color and improved the taste and smell.

Received | November 10, 2021; Accepted | December 25, 2021; Published | December 30, 2021

*Correspondence | Damat Damat, Department of Food Technology, Faculty of Agriculture and Animal Science, University of Muhammadiyah Malang, J1. Raya Tlogomas No.246, Malang, 65144, Indonesia; Email: damatumm@gmail.com

Citation | Damat, D., R.H. Setyobudi, J. Burlakovs, Z.V. Gaile, D.D. Siskawardani, R. Anggriani and A. Tain. 2021. Characterization properties of extruded analog rice developed from arrowroot starch with addition of seaweed and spices. Sarhad Journal of Agriculture, 37(Special issue 1): 159-170.

DOI | https://dx.doi.org/10.17582/journal.sja/2021.37.s1.159.170

Keywords $\mid$ Artificial rice, Analog rice, Food sovereignty, Functional food, Antioxidant activity and fiber

\section{Introduction}

$\mathrm{R}$ ice is an Indonesian staple food, but The Nation's Dependence on rice is not matched byits domestic production. Indonesian statistical data show that in 2019 rice consumption reached $35300 \times 10^{6} \mathrm{yr}^{-1}$.
Moreover, Indonesia imported 800000 t from neighboring countries. Rice imports between 2010 to 2019 were very volatile, highly dependent on domestic rice production. For example, in 2017, rice imports were $305275 \mathrm{t}$. While in 2018, rice imports rose to $2253824 \mathrm{t}$, and in 2019 imports fell to 
444508 t. (Pudjiastuti et al., 2021). This proves that Indonesia is weak in national food security, therefore, food diversification is crucial. Analog rice, artificial rice produced from non-paddy carbohydrates could become an alternative that replaces rice as the primary food and contains almost the same or a higher nutrition value than paddy rice (Oo and Than, 2019).

Analog rice is a product shaped like rice but produced from non-rice materials. It has a carbohydrate content approaching or exceeding the level of rice produced from local food flour, which is not rice but is cooked in the same way that rice is cooked (Mishra et al., 2012; Wahjuningsih et al., 2018). Furthermore, it can be designed to have almost the same nutritional value as even rice, and also has functional properties, depending on the raw materials used. In general, analog rice is produced from ingredients that have high carbohydrate content, such as sweet potato [Ipomoea batatas (L.) Lam.], cassava (Manihot esculenta Crantz), sago palm (Metroxylon sagu Rottb), sorghum [Sorghum bicolor (L.) Moench], and other ingredients (Sumardiono et al., 2014). Based on the results of previous studies, it is known that analog rice has weaknesses; namely, the taste is bland, and in general, its antioxidant activity is also low. A study has been carried out on analog rice products produced from different ingredients, including sorghum (Budijanto and Yuliyanti, 2015; Wahjuningsih et al., 2018), composite flour (Sumardiono et al., 2014), sago flour, and arrowroot (Pudjihastuti et al., 2019), taro [Colocasia esculenta (L.) Schott] and seaweed (Darmanto et al., 2017), cassava, avocado seeds (Persea Americana Mill.), tofu waste (Putri and Sumardiono, 2020), sago, and red beans (Phaseolus vulgaris L.) (Wahjuningsih et al., 2020), sweet potato flour and carrot (Daucus carota L. var. sativus.) (Anggraini et al.,2016), and cornflour (Zea mays L.) and Gracilaria spp. seaweed (Purwaningsih et al., 2020), predicted the glycemic index of rice analog from modified arrowroot starch (Damat et al., 2021).

Arrowroot (Maranta arundinacea L.) can grow well in Indonesia and can survive in various types of soil at different altitudes, and productivity reaching $17 \mathrm{t} \mathrm{ha}^{-1}$ (Djafaar and Pustika, 2010). According to Djaafar and Pustika (2010), arrowroot productivity is relatively high, reaching an average of $20 \mathrm{tha}^{-1}$. A new substance is formed when arrowroot is processed into a starch product, known as resistant starch. Astuti et al. (2018), the resistant starch in arrowroot flour is about $22.56 \%$. Furthermore, resistant starch is a fraction of starch that resists hydrolysis by digestive enzymes. Its compact molecular structure can prevent damage by enzyme digestion, which can lead to blood glucose. Therefore, the resistant starch is considered suitable for diabetics (Damat et al., 2019a; Damat, 2013; Fuentes-Zaragoza et al., 2010; Shukri and Shi, 2015).

The red seaweed (Gracilaria spp.) is the primary source of hydrocolloids, it contains functional components such as high dietary fiber that can absorb water and bind glucose, reducing the availability of glucose in the body, and stabilizing blood glucose (Carlson, 2018). In addition, red seaweed is also rich in antioxidants, nucleic acids, amino acids, and vitamins (A, B, C, $\mathrm{D}, \mathrm{E}$, and $\mathrm{K}$ ). Minerals such as nitrogen, calcium, selenium, manganese, and sodium, are detected in red seaweed. The content of amino, vitamins, and minerals in red seaweed is 10 to 20 times higher than plants that grow on the land (Chan et al., 2014). The use of red seaweed flour is expected to add the functional properties of analog rice.

There have been many studies that reveal a lot of studies have been carried out on analog rice, it still has weaknesses. The aroma of analog rice is less favorable, and its antioxidant activity is relatively low. "Yellowcooked rice", one of the Indonesian traditional recipes, uses a variety of spices including shallot (Allium cepa var. aggregatum G. Don), garlic (Allium sativum L.), ginger (Zingiber officinale Roscoe), turmeric (Curcuma longa L.), and lemongrass (Cymbopogon schoenanthus (L.) Spreng] (Raghavan, 2017). The combination of the spices creates a pleasant aroma and applying this recipe into analog rice formula is expected to improve consumer preference. The spices also contain antioxidants, which leads to the addition of functional value to analog rice (Shahidi and Ambigaipalan, 2015). Shallot and garlic have antioxidants activity of about $70.7 \%$ and $77.4 \%$, respectively (Mnayer et al., 2014), while the activity of antioxidants derived from ginger, turmeric, and lemongrass are $27.0 \%, 67.8 \%$, and $10.4 \%$, respectively (Sepahpour et al., 2018).

There is no study has been carried out on the analog rice produced from a mixture of arrowroot starch, Glacilaria spp. seaweed extract, and spices. However, the use of spices as a source of antioxidants in analog rice has also not been identified. The mixture of these three ingredients is expected to produce analog rice with a distinctive aroma that consumers such as well as an increase in antioxidant activity. Therefore, the 
study aims to determine the impact of the addition of variations in seaweed pulp concentrations and spice formulations on the characteristics of arrowroot starch-based analog rice. The goal of the future development is to study was expected to produce functional analog rice, which would be sufficiently tasty by using local food sources and would help the nation to strengthen its food sovereignty.

\section{Materials and Methods}

\section{Preparation of raw materials}

Arrowroot starch was obtained from farmers in Poncokusumo District, Malang Regency, East Java, Indonesia. Gracilaria spp. collected from the farmers in Sidoarjo Regency, East Java. The first treatment was to wash it before soaking it in brine for $24 \mathrm{~h}$. Then, the seaweed was blended with $60 \mathrm{~mL}$ of water.

Fresh spices of shallots (Allium cepa var. aggregatum G. Don.), garlic (Allium sativum L.), ginger (Zingiber officinale Roscoe), turmeric (Curcuma longa L.), and lemongrass (Cymbopogon schoenanthus (L.) Spreng.), were also obtained from farmers in Karangploso District, Malang Regency, East Java, Indonesia. The fresh spices were peeled, washed, and blended with $60 \mathrm{~mL}$ of water.

\section{Formulation}

The ingredient formulation consisted of $100 \%$ arrowroot starch, mixed with seaweed pulp in quantities of $5 \mathrm{~g}, 10 \mathrm{~g}$, and $15 \mathrm{~g}$. Along with spice variations, the total amount of spices used in each formula was $69 \mathrm{~g}$. In addition, salt was added as a seasoning and GMS (Glycerol Monostearate) as an emulsifier. The exact formula is presented in Table 1. Rojolele rice was used as a control against analog rice.

\section{Extrusion}

The ingredients were mixed and Maspion steamer SKU 15448 for $30 \mathrm{~min}$ at $80{ }^{\circ} \mathrm{C}$, steamed materials were directly inserted into a Barata Indonesia extruder, model BA-05 to form the analog rice. After analog rice granules were formed, they were dried in a Maksindo cabinet dryer at $50{ }^{\circ} \mathrm{C}$ for $20 \mathrm{~h}$ until the water content reaches $8 \%$ to $10 \%$.

\section{Nutrition Analysis}

The nutrition analysis of dried analog rice was carried out to determine the water content, fat content with soxhlet, protein levels using Kjeldahl methods (SáezPlaza et al., 2013; William and Latimer, 2019), while the calculation of carbohydrate content uses the carbohydrate by difference method. The fiber level was estimated with a Fibra plus equipment, and the residue obtained after digestion with acid and alkali was dried in a crucible and weighed. The difference in weight of the crucible before and after washing the digested residues was taken as crude fiber weight ( $\mathrm{Li}$ and Komarek, 2017; Puwastien et al., 2011). Reference was made to the AOAC 2002.02 method for resistant starch content found McCleary et al. (2019).

Table 1: Formulation of analog rice from arrowroot starch with addition of seaweed and spices.

$\begin{array}{llllllllll}\text { Treatment } & \text { F1 } & \text { F2 } & \text { F3 } & \text { F4 } & \text { F5 } & \text { F6 } & \text { F7 } & \text { F8 } & \text { F9 } \\ \begin{array}{l}\text { Dry material: } \\ \text { Carbohydrate }\end{array} & 500 & 500 & 500 & 500 & 500 & 500 & 500 & 500 & 500 \\ \begin{array}{l}\text { source (g) } \\ \text { Water (mL) }\end{array} & 60 & 60 & 60 & 60 & 60 & 60 & 60 & 60 & 60 \\ \begin{array}{l}\text { Emulsifier: GMS } \\ \text { (g) }\end{array} & 10 & 10 & 10 & 10 & 10 & 10 & 10 & 10 & 10 \\ \text { Seasoning: Salt (g) } & 3 & 3 & 3 & 3 & 3 & 3 & 3 & 3 & 3 \\ \text { Seaweed pulp (g) } & 5 & 5 & 5 & 10 & 10 & 10 & 15 & 15 & 15 \\ \text { Spices } & & & & & & & & & \\ \text { Shallots (g) } & 35 & 15 & 25 & 35 & 15 & 25 & 35 & 15 & 25 \\ \text { Garlic (g) } & 15 & 35 & 25 & 15 & 35 & 25 & 15 & 35 & 25 \\ \text { Ginger (g) } & 4 & 8 & 6 & 4 & 8 & 6 & 4 & 8 & 6 \\ \text { Turmeric (g) } & 9 & 5 & 7 & 9 & 5 & 7 & 9 & 5 & 7 \\ \text { Lemongrass (g) } & 6 & 6 & 6 & 6 & 6 & 6 & 6 & 6 & 6\end{array}$

\section{Activity of antioxidant}

The antioxidants activity evaluated was observed for both uncooked and cooked analog rice using the radical scavenging activity method (Valdez-Morales et al., 2014).

Each sample of each treatment was taken with a measuring pipette of $0.2 \mathrm{~mL}$. Then the sample was placed into the test tube and a $500 \mu \mathrm{M}$ DPPH solution of $3.8 \mathrm{~mL}$ each were added. The solution was homogenized with vortex and then incubated in a dark room for $30 \mathrm{~min}$. Furthermore, the sample was absorbed by a UV-Vis spectrophotometer UV-vis Shimadzu UV-1800 with a maximum wavelength of DPPH. The antioxidant activity was calculated using Equation (1):

$$
\text { (\%) Inhibition }=\frac{\text { Abs. Blank }- \text { Abs.Sample }}{\text { Abs. Blanko }} \times 100 \%
$$

Where;

Abs. Blank $=50 \mu \mathrm{M}$ DPPH Absorbance

Abs. Sample = Absorbance of Sample. 
Physical characteristics

Determination of water absorption index (WAI): The water absorption index (WAI) was determined by Yousf et al. (2017). Furthermore, $2 \mathrm{~g}$ of sample were suspended in $20 \mathrm{~mL}$ of distilled water, kept in the water bath for $5 \mathrm{~min}$ at $80{ }^{\circ} \mathrm{C}$. Subsequently, the dispersions were rained, and their weight was measured by Equation (2):

$$
\text { WAI }=\frac{\text { Weight of rice before cooking }+ \text { Weight of rice after cooking }}{\text { Weight of rice before cooking }} \times 100 \%
$$

Color measurements: Color measurements were performed on both uncooked and cooked analog rice using a Hunter lab Konica Minolta Color Reader Type CR-10 Plus. The method was described by Pathare et al. (2013). L values correspond to the lightness/dark color of the product, with higher values corresponding to greater lightness. The $\mathrm{a}$ and $\mathrm{b}$ values correspond to the color dimensions of an object, with the values describing the red to the green of a sample, while the $b$ values describe the yellow to a bluish color of a sample. The larger a-value indicates more redness and the larger of a b-value indicates more yellowness.

Sensory evaluation: Sensory evaluation was carried out by 24 examiners who were trained using the sevenpoint hedonic evaluation scale by Stefanowicz (2013) for sensory attributes such as taste, aroma, uniformity of form, texture, and overall acceptability. Taste Score includes 1 . very bad/not tasty; 2 . moderate, not tasty; 3. a bit tasty; 4. slightly tasty; 5. tasty; 6. moderately tasty; 7. very tasty. Aroma Score: 1. very weak; 2. moderately weak; 3 . slightly weak; 4. slightly strong; 5.moderatelystrong; 6.strong; and7.verystrong.Texture Score: 1 . very not chewy; 2 . moderately not chewy; 3. slightly not chewy; 4 . slightly chewy; 5 . moderately chewy; 6. chewy; 7. very chewy. Uniformity of grain score includes 1 . very not uniform; 2 moderately not uniform; 3. slightly not uniform; 4. slightly uniform; 5. moderately uniform; 6. uniform; 7. very uniform. Overall Acceptability Score 1. very unacceptable; 2. moderately unacceptable; 3 . slightly unacceptable; 4. slightly acceptable; 5. moderately acceptable; 6. Acceptable, and 7. very acceptable.

\section{Statistical analysis}

A Randomized Block Design (RBD) with three replications, consisting of nine treatments were used. The data were analyzed by ANOVA using SPSS version 25 and continued to Duncan's multiple range test with a probability $(P<0.05)$ (Adinurani, 2016). Data from the analysis of analog rice were compared with the physicochemical properties of Oryza sativa L. cv. Rojolele.

\section{Results and Discussion}

\section{Nutrition analysis}

The proximate compositions of analog rice with the addition of red seaweed and spices are shown in Table 2. The results are compared with cv. Rojolele.

Table 2: Nutrition of arrowroot starch-based analog rice with the addition of seaweed and spices.

\begin{tabular}{|c|c|c|c|c|c|c|}
\hline $\begin{array}{l}\text { For- } \\
\text { mula }\end{array}$ & RS & $\begin{array}{l}\text { Water } \\
\text { content } \\
\text { (\%) }\end{array}$ & $\begin{array}{l}\text { Protein } \\
\text { (\%) }\end{array}$ & Fat (\%) & Carbs (\%) & $\begin{array}{l}\text { Fiber } \\
\text { (\%) }\end{array}$ \\
\hline F1 & $15.82^{\mathrm{ab}}$ & $8.709^{a b c}$ & $0.136^{\mathrm{abc}}$ & $1.444^{\mathrm{bc}}$ & $88.943^{\operatorname{defg}}$ & $20.939^{\mathrm{abc}}$ \\
\hline $\mathrm{F} 2$ & $15.11^{\mathrm{a}}$ & $8.706^{a b}$ & $0.133^{\mathrm{ab}}$ & $1.378^{\mathrm{b}}$ & $89.093^{\text {defgh }}$ & $20.899^{a b}$ \\
\hline F3 & $16.02^{\mathrm{ab}}$ & $8.504^{a}$ & $0.131^{a}$ & $1.150^{\mathrm{a}}$ & $89.362^{\text {defgh }}$ & $20.703^{a}$ \\
\hline $\mathrm{F} 4$ & $16.66^{c}$ & $9.783^{\text {ef }}$ & $0.182^{\mathrm{de}}$ & $2.34^{\text {def }}$ & $87.496^{\mathrm{abcd}}$ & $24.795^{\mathrm{ef}}$ \\
\hline F5 & $16.70^{c}$ & $9.459^{\mathrm{e}}$ & $0.182^{\mathrm{d}}$ & $2.108^{\mathrm{de}}$ & 87.849 $9^{\text {abcde }}$ & $23.717^{\mathrm{d}}$ \\
\hline F6 & $16.75^{\mathrm{cd}}$ & $9.067^{\mathrm{d}}$ & $0.186^{\text {def }}$ & $2.080^{\mathrm{d}}$ & $88.217^{\text {bcdef }}$ & $24.691^{\mathrm{e}}$ \\
\hline F7 & $17.58^{\mathrm{e}}$ & $10.564^{\mathrm{h}}$ & $0.212^{\mathrm{gh}}$ & $3.078^{\mathrm{gh}}$ & $86.041^{a}$ & $30.550^{\mathrm{g}}$ \\
\hline F8 & $17.60^{\mathrm{e}}$ & $10.482^{\mathrm{h}}$ & $0.197^{\text {defg }}$ & $3.044^{\mathrm{g}}$ & $86.157^{\mathrm{ab}}$ & $30.805^{\mathrm{gh}}$ \\
\hline F9 & $17.43^{\mathrm{f}}$ & $10.140^{\mathrm{g}}$ & $0.203^{\text {fgh }}$ & $3.061^{\mathrm{gh}}$ & $86.480^{\mathrm{abc}}$ & $30.810^{\mathrm{gh}}$ \\
\hline $\begin{array}{l}\text { cv. Ro- } \\
\text { jolele* }\end{array}$ & ND & 13.00 & 8.4 & 1.70 & 77.11 & ND \\
\hline
\end{tabular}

The numbers followed by letters that are not equal indicate a noticeable difference according to a test of Duncan $\alpha 5 \%$.

ND: Not detected; RS: Resistant starch

*: Sumardiono et al. (2014)

The resistant starch content of analog resistant rice ranged from $15.82 \%$ to $17.43 \%$. This indicates that the higher the concentration of Gracilaria spp. seaweed pulp added, the higher the level of resistant starch increased. According to the fiber content of fresh and dried in Gracilaria spp. seaweed reaches $11.2 \%$ and $27.48 \%$ approximately (Purwaningsih et al., 2020; Rasyid et al., 2019). The fiber consists of resistant starch and non-starch polysaccharide (Holscher, 2017). The high fiber of analog rice due to Gracilaria spp. seaweed pulp shown in Table 2 is suspected to contribute to the resistant starch of analog rice. Meanwhile, the addition of spices is assumed to not affect increasing the resistant starch of analog rice. The role of spices is to contribute distinctive aroma and antioxidant resources. 
High levels of resistant starch can also be caused by the reaction between the emulsifier glyceryl monostearate (GMS) and amylose. Amylose can bind to fats and proteins, which will complicate the enzyme lead to starch digestibility decreases. Furthermore, GMS is an emulsifier with one of the structures of stearic fatty acids, which can bind to amylose to form a matrix. This binding decreases the water absorption of the matrix. Consequently, gelatinization does not occur optimally. This correlates with the difficulty of enzymes breaking down starch into simpler structures, which lead to low starch digestibility (Magallanes-Cruz et al., 2017; Susi et al., 2019). The addition of glycerol monostearate in starch forms an emulsified starch complex that stabilizes the granules and delays water penetration and swelling, thereby decreasing starch digestibility (Garcia and Franco, 2015; Yang et al., 2017).

The water content of the analog rice showed significant differences between the formulas, ranging from $8.504 \%$ to $10.564 \%$, with the lowest and the highest moisture content approaching that of Formula 3 and Formula 7 , respectively. By using the number followed by the letters in the Duncan test, it was shown that the higher amount of seaweed added, the higher the moisture content would be obtained, due to the high moisture contained in seaweed. According to Keyimu (2013), the water content of Gracilaria spp. was $41.96 \%$. Although the addition of seaweed increased the moisture content of the analog rice, the value was lower than cv. Rojolele. Moreover, the moisture content of the analog rice in all formulas met the SNI (Standard Nasional Indonesia = Indonesian National Standard) that the water content of rice should be below $14 \%$ (Sarastuti et al., 2019).

The protein levels increased with the addition of seaweed pulp, which is indicated by the different letters that follow the numbers. Gracillaria spp. contain protein up to $12.57 \%$ (Chan and Matanjun, 2016), even reached $41 \%$ to $45 \%$ (Francavilla et al., 2013), while arrowroot starch displayed $0.60 \%$ (Aprianita et al., 2013). SNI (Standard Nasional Indonesia $=$ Indonesia National Standards) Rice No. 6128-2008 states that there is no minimum protein requirement for rice, but the Ministry of Health no. 6128-2008, Republic of Indonesia, recommends that analog rice contain $6.8 \%$ protein. In contrast, the protein content of the analog rice in this study was less than $1 \%$, which is lower than cv. Rojolele. The low protein of the analog rice in this study is predicted at the least amount of seaweed added. Similar to protein data, the fat of analog rice also increases with the addition of seaweed, this can be seen from the different letters that follow each number. According to Chan and Matanjun (2017), Gracillaria spp. has a fat content of $11.05 \%$. Meanwhile, it was predicted that the spices do not contribute to fat, the fat of spices was not more than $1 \%$ such as for ginger, shallot, garlic, and turmeric just has $1 \%, 0.3 \%, 0.5 \%$, and $0.9 \%$ respectively (El-Sayed and Youssef, 2019). The fat of analog rice ranged from $1.150 \%$ to $3.061 \%$, while cv Rojolele has $1.70 \%$. Therefore, this level is similar to milled rice and analog rice derived from groats with destruction ranging from $2.9 \%$ to $3.4 \%$ and $0.3 \%$ to $3.7 \%$, respectively (Olia et al., 2014; Purwaningsih et al., 2019).

A contrast phenomenon occurs in the carbohydrate content of the analog rice, which showed no significant difference in each formula since it was followed by the same letter in the Duncan test. This indicated that the material that contributed to the carbohydrate content of the analog rice was derived from arrowroot starch, which has $89.88 \%$ of carbohydrates (Wahyuningsih and Susanti, 2018). The carbohydrate in this study is higher than cv. Rojolele, which was measured at 78.9\%. Other studies on analog rice have an average value of carbohydrate content of less than $85 \%$ (Budijanto and Yulianti, 2015).

The fiber content of the analog rice in this study reached up to $31 \%$. Higher amounts of seaweed resulted in higher levels of fiber. According to Purwaningsih et al. (2019), seaweed has a food fiber content of $11.20 \%$. Meanwhile, the spices were determined not to have fiber content, and arrowroot starch also had low fiber (Wahjuningsih et al., 2018). The analog rice fiber content in this study was higher than any polished rice, which only has $5 \%$ to $6 \%$ (Oo and Than, 2019). Pudjihastuti et al. (2019) stated that analog rice has a food fiber content of $5 \%$. Head of the Food and Drug Supervisory Agency No. 22-2019 suggests that food products can be a source of fiber if they contained more

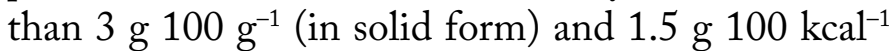
(in liquid form). The regulations stipulate that high fiber products or foodstuff, should not contain less than $6 \mathrm{~g} 100 \mathrm{~g}^{-1}$ (in solid form) or $3 \mathrm{~g} 100 \mathrm{kcal}^{-1}$ (in liquid form). According to these statements, the analog rice in this study can be categorized as a product with high fiber because it is made up of more than $6 \%$ of food fiber. 
Antioxidant activity

A comparison of the antioxidant activity between pre-and post-cooked analog rice is shown in Table 3. The antioxidant activity of the analog rice was more significant than cooked rice. This condition showed that heating influence the stability of antioxidant. According to Hur et al. (2014) high temperatures destroy the antioxidant compound. Moreover, Shahidi and Ambigaipalan (2015) stated that oxygen, alkali, light, minerals, and hydroperoxides degrade a-tocopherol. The presence of food moisture and atmospheric oxygen can promote chemical changes and antioxidant loss (Hur et al., 2014).

Table 3: Comparison of antioxidant activity in pre-and post-cooked of arrowroot starch-based analog rice with the addition of seaweed and spices.

$\begin{array}{lll}\text { Formula } & \begin{array}{l}\text { The activity of antioxidant (\%) } \\ \text { Cooked Rice }\end{array} \\ \text { Fice } & 34.724^{\text {defg }} & 21.238^{\text {cdef }} \\ \text { F2 } & 26.653^{\mathrm{a}} & 20.734^{\mathrm{cde}} \\ \text { F3 } & 32.994^{\mathrm{cd}} & 16.091^{\mathrm{ab}} \\ \text { F4 } & 34.215^{\mathrm{def}} & 24.946^{\mathrm{fg}} \\ \text { F5 } & 28.077^{\mathrm{ab}} & 30.490^{\mathrm{h}} \\ \text { F6 } & 29.705^{\mathrm{abc}} & 26.998^{\mathrm{gh}} \\ \text { F7 } & 38.861^{\mathrm{h}} & 19.762^{\mathrm{bcd}} \\ \text { F8 } & 34.113^{\text {de }} & 19.222^{\mathrm{bc}} \\ \text { F9 } & 35.605^{\text {defgh }} & 13.175^{\mathrm{a}} \\ \text { cv. Rojolele* }^{*} & \mathrm{ND} & \mathrm{ND}\end{array}$

The numbers from the letters that do not equal indicate a noticeable difference according to a Duncan $\alpha 5 \%$ test.

ND: Not Detected.

*: Sumardiono et al. (2014)

The component that contributed to the antioxidant activity was predicted from the spices added. Different amounts of spices in each formula induced led to antioxidant activity detected. According to Asouri et al. (2013) antioxidant activity in the form of curcumin levels in turmeric is more than $62.0 \%$. Subsequently, onion has a flavonoids content of quercetin conjugation that can retain its stability up to the temperature of $100{ }^{\circ} \mathrm{C}$. At the same time, the total polyphenol of garlic extract in ethanol ranged from $559 \mathrm{mg} \mathrm{kg}^{-1}$ to $763 \mathrm{mg} \mathrm{kg}^{-1}$ (Micova et al., 2018).

The ginger extract in the water solvent contains a total of polyphenols, tannins, and flavonoids, reaching $840 \mathrm{mg} 100 \mathrm{~g}^{-1}, 1.51 \mathrm{~g} 100 \mathrm{~g}^{-1}$, and $2.98 \mathrm{~g} 100 \mathrm{~g}^{-1}$, respectively (Shirin and Prakash, 2010). Kanatt et al.
(2014) reported that lemongrass extract contains total phenolics and flavonoids of about $100 \mathrm{mg}$ and $30 \mathrm{mg}$, respectively, and both spices and seaweed generated antioxidant activity. Gracillaria spp, which is classified as a red algae (Rhodophyta Wettstein), contains chlorophyll with phycobilin and carotenoids, also has antioxidant activity (Chan et al., 2014). Although the antioxidant activity of analog rice in this study was categorized as low capacity (less than $50 \%$ ), this can be considered as a functional food by reformulating the number of spices and amount of seaweed to increase antioxidant activity.

\section{Physical characteristics}

The physical characteristics of the analog rice are presented in Table 4. The WAI was found to be insignificant according to the formula, which had the same amount of seaweed added. However, the more seaweed added, the less WAI detected. Water absorption is the amount of water absorbed by the flour to create a dough with a malleable consistency. It is determined by the protein content of the flour, the starch damaged during milling, and the presence of non-starch carbohydrates (Murray et al., 2017). Seaweed contains fiber as a non-starch carbohydrate, dietary fiber consists of polysaccharides with $\beta$ (1-4) bonds, which cannot be digested by the salivary glands and pancreas but can be metabolized bacteria present in in the large intestine and produce shortchain fatty acid (SCFA) (Damat, 2013; Holscher, 2017). Starchy foods absorb water more easily due to the availability of reactive amylopectin molecules from water molecules (Magallanes-Cruz et al., 2017).

The $L$ value (brightness) of the analog rice in this study was varied and ranged from 69 to 72 when the effect of various amounts of spices was added (Table 4). This indicated that the analog rice was considered bright (Figure 1a), similar to the cv. Rojolele, which had an $\mathrm{L}$ value of 72 . However, after cooking, the $\mathrm{L}$ value of the analog rice dropped to $49 \%$ (Table 4), which indicated a darker color than before cooking (Figure 1b).

The yellowness of the analog rice in this study was more intense than cv. Rojolele (Table 4). The yellow color was derived from curcuminoid as a pigment in turmeric, which is added up to $5 \%$ (Nelson et al., 2017). The cooking process decreased the brightness and increased the yellowness of the analog rice (and vice versa). Priyadarsini et al. (2014) claimed that the 
Table 4: The physical characteristics of arrowroot starch-based analog rice with the addition of seaweed and spices.

\begin{tabular}{|c|c|c|c|c|c|}
\hline \multirow[t]{2}{*}{ Formula } & \multirow{2}{*}{$\begin{array}{l}\text { Water Absorbant In- } \\
\text { dex/ WAI (\%) }\end{array}$} & \multicolumn{2}{|c|}{ L (brightness) } & \multicolumn{2}{|c|}{ b+ (yellowness) } \\
\hline & & Rice & Cooked Rice & Rice & Cooked Rice \\
\hline $\mathrm{F} 1$ & $320.508^{\mathrm{gh}}$ & $70.533^{\text {bcde }}$ & $50.267^{\mathrm{ab}}$ & $25.433^{\mathrm{i}}$ & $27.400^{\mathrm{i}}$ \\
\hline $\mathrm{F} 2$ & $316.943^{g}$ & $72.233^{\mathrm{i}}$ & $52.700^{\mathrm{h}}$ & $23.233^{\text {cd }}$ & $25.233^{\text {bcdef }}$ \\
\hline F3 & $321.228^{\mathrm{gh}}$ & $71.100^{\text {defgh }}$ & $51.500^{\mathrm{efg}}$ & $24.333^{\mathrm{gh}}$ & $25.700^{\text {cdefg }}$ \\
\hline $\mathrm{F} 4$ & $265.499^{\mathrm{de}}$ & $69.100^{a}$ & $50.467^{\mathrm{bcd}}$ & $24.200^{\mathrm{g}}$ & $26.233^{\mathrm{fgh}}$ \\
\hline F5 & $276.175^{\mathrm{ef}}$ & $70.800^{\text {cdef }}$ & $52.200^{\text {efgh }}$ & $22.367^{\mathrm{a}}$ & $24.667^{\mathrm{bc}}$ \\
\hline F6 & $258.841^{\mathrm{d}}$ & $70.000^{\mathrm{bc}}$ & $51.300^{\text {cde }}$ & $23.267^{\text {cde }}$ & $25.033^{\text {bcde }}$ \\
\hline F7 & $182.718^{\mathrm{ab}}$ & $69.767^{\mathrm{ab}}$ & $49.567^{\mathrm{a}}$ & $23.300^{\text {cdef }}$ & $24.867^{\mathrm{bcd}}$ \\
\hline F8 & $182.873^{\mathrm{abc}}$ & $71.000^{\operatorname{defg}}$ & $51.333^{\text {def }}$ & $22.467^{\mathrm{ab}}$ & $23.500^{\mathrm{a}}$ \\
\hline F9 & $182.698^{\mathrm{a}}$ & $70.300^{\mathrm{bcd}}$ & $50.433^{\text {bc }}$ & $23.033^{\mathrm{bc}}$ & $24.333^{\mathrm{ab}}$ \\
\hline cv. Rojolele $^{*}$ & ND & 72.57 & ND & 8.64 & ND \\
\hline
\end{tabular}

The numbers followed by the letters that do not equal indicate a noticeable difference according to a Duncan $\alpha 5 \%$ test.

ND: Not Detected. *: Sumardiono et al., (2014)

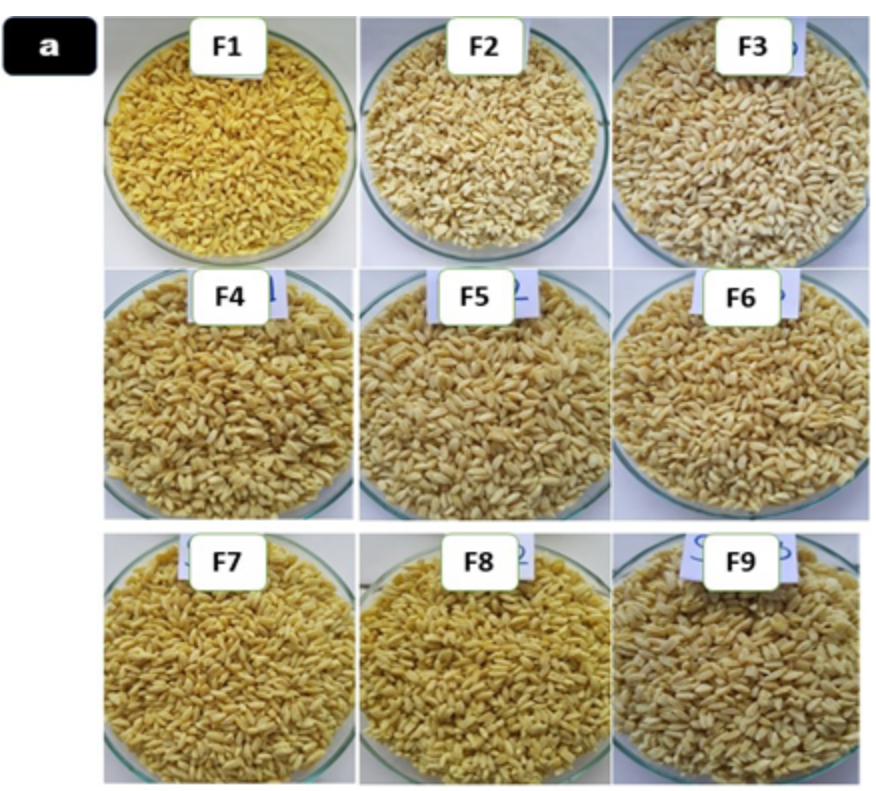

\section{b}
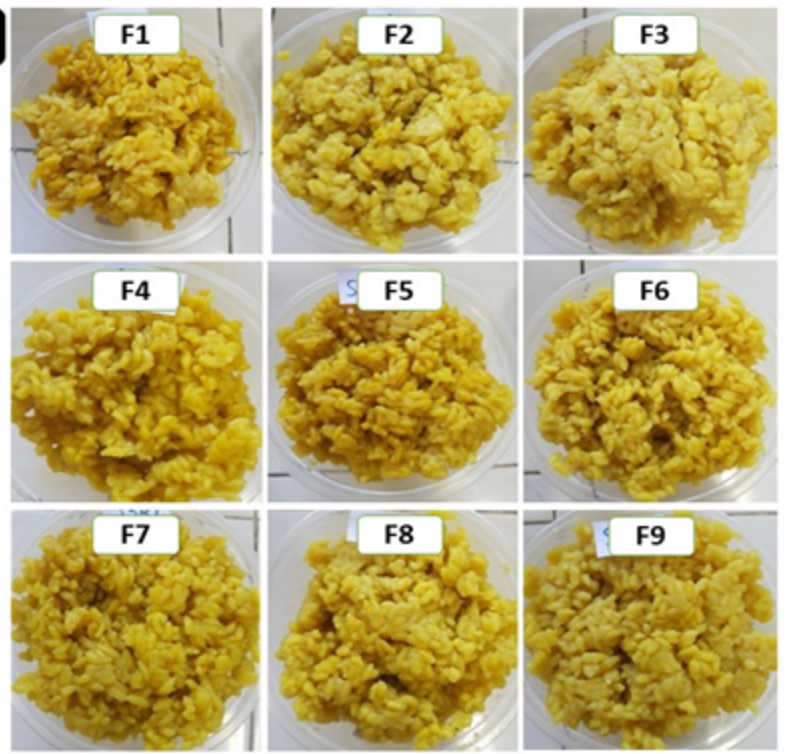

Figure 1: The color of the raw analog rice (a) and cooked analog rice (b) with the addition of seaweed and spices. colorvalue of heat-treated turmeric powder isenhanced at higher temperatures. In addition, the action of polyphenol oxidase (PPO) triggers the browning reaction and leads to the dark brown color of turmeric.

\section{Sensory Characteristic of the Cooked Analog Rice}

Table 5 presents the average score of the sensory characteristic of the analog rice in the various formulas. The taste and aroma scores of the analog rice showed a significant difference in several formulas. Each spice contains volatile compounds that caused a distinctive smell and complex flavor. For example, turmeric produces a bitter and smelly flavor (Vallverdú-Queralt et al., 2015). However, these flavors combinations are challenging to interpret. There are several volatile responsible for a flavor sensation, while combinations of volatiles yield different flavors cause different perceptions (Chamber and Kadri, 2013). Moreover, the person evaluating these sense were an untrained panelist. However, the taste and aroma of analog rice with grades from 3.4 to 4.2 were rather "slightly tasty", while the aroma score ranged from 3.9 to 5.2, suggesting a strong aroma.

The score of texture and uniformity of grain were predicted by the seaweed effect, which is supported by the data of water content (Table 2) and WAI (Table 4). Furthermore, carrageenan found in seaweed plays a role in the formation of chewy textures. According to Prajapati et al. (2014), seaweed produces carrageenan that can react and function well with sugar, starch, gum, and other materials, the formation of the gel was due to the double helix structure of the carrageenan. Arrowroot starch, the raw material of analog rice 
caused a chewier texture compared to the texture of the rice selected as the comparison group. The amylose to amylopectin ratio present in starch contributes to the hardness and toughness of cooked rice (Damat et al., 2019b). It can be indicated that the higher the amylose levels in the rice, the harder the rice texture and vice versa. Arrowroot starch contained $21.9 \%$ of amylose and $62.3 \%$ of amylopectin (Aprianita et al., 2013). Boiled arrowroot starch cause gelatinization, which coats the surface of the cooked grains (Tamura and Ogawa, 2012), contributing to the improvement of rice-eating quality (Wada et al., 2010). The texture and uniformity of the analog rice grain received a positive assessment from the panelist. The texture ranged from 3.8 to 5.1 and tended to be chewy, but if the uniformity of grain ranged from 3.9 to 5.2 , then tend to be uniform.

Table 5: Sensory characteristics of cooked arrowroot starch-based analog rice with the addition of seaweed and spices.

\begin{tabular}{llllll} 
Formula & Taste & Aroma & Texture & $\begin{array}{l}\text { Uniformity Overall Ac- } \\
\text { of grain }\end{array}$ & $\begin{array}{l}\text { Optability } \\
\text { cepta }\end{array}$ \\
\hline F1 & $4.083^{\mathrm{cd}}$ & $4.625^{\mathrm{b}}$ & $5.167^{\mathrm{egh}}$ & $5.375^{\mathrm{efg}}$ & $3.792^{\mathrm{e}}$ \\
F2 & $3.333^{\mathrm{a}}$ & $4.917^{\mathrm{bc}}$ & $4.208^{\mathrm{abc}}$ & $3.833^{\mathrm{ab}}$ & $3.208^{\mathrm{a}}$ \\
F3 & $3.792^{\mathrm{c}}$ & $4.875^{\mathrm{bc}}$ & $3.875^{\mathrm{a}}$ & $3.250^{\mathrm{a}}$ & $3.583^{\mathrm{c}}$ \\
F4 & $3.833^{\mathrm{cd}}$ & $4.708^{\mathrm{bc}}$ & $4.250^{\mathrm{abcd}}$ & $4.792^{\mathrm{e}}$ & $3.458^{\mathrm{bc}}$ \\
F5 & $4.167^{\mathrm{cd}}$ & $5.125^{\mathrm{bc}}$ & $5.000^{\mathrm{cdefg}}$ & $5.708^{\mathrm{fgh}}$ & $3.625^{\mathrm{cd}}$ \\
F6 & $4.292^{\mathrm{d}}$ & $5.292^{\mathrm{d}}$ & $4.875^{\mathrm{bcdef}}$ & $5.958^{\mathrm{gh}}$ & $4.083^{\mathrm{ef}}$ \\
F7 & $3.500^{\mathrm{b}}$ & $3.958^{\mathrm{a}}$ & $5.000^{\text {cdefgh }}$ & $5.083^{\mathrm{ef}}$ & $3.333^{\mathrm{b}}$ \\
F8 & $3.792^{\mathrm{c}}$ & $4.958^{\mathrm{bc}}$ & $4.125^{\mathrm{ab}}$ & $3.958^{\mathrm{abcd}}$ & $3.208^{\mathrm{ab}}$ \\
F9 & $3.417^{\mathrm{ab}}$ & $5.125^{\mathrm{bc}}$ & $4.458^{\mathrm{abcde}}$ & $3.875^{\mathrm{abc}}$ & $3.458^{\mathrm{bc}}$
\end{tabular}

The numbers followed by the letters that do not equal indicate a noticeable difference according to a test Duncan $\alpha 5 \%$.

The overall acceptability scores of the analog rice ranged from 3.2 to 4.0 , indicating that it is slightly acceptable. The panelists stated that the analog rice was less salty and had a slightly bitter taste. The panelists selected the F6 as the best formula, which has the character of a slightly tasty, chewy, uniform grain and flavorful aroma.

\section{Conclusions and Recommendations}

The use of seaweed and spices mixed with arrowroot starch can produce the desired analog rice quality, similar to the cv. Rojolele in water content and carbohydrate. The water content of analog rice in this study fulfilled the Indonesian standard requirement.
The addition of seaweed also increases the fiber content and resistant starch content of the analog rice, which can be categorized as a high fiber product. Meanwhile, the addition of spices contributes to antioxidant activity and consumer acceptance. The spices help analog rice to be colorful and to have a flavorful aroma, the modified analog rice can serve as an alternative functional food.

\section{Acknowledgments}

The authors express profound gratitude to the Ministry of Research and Technology, the Republic of Indonesia Grant Number: 119/SP2H/LT/MULTI/ L7L2019, for funding this research.

\section{Novelty Statement}

Many types of research on analog rice have been carried out, but the analog rice produced still has weaknesses. Among others, it still has a flour aroma and has relatively low levels of antioxidants. In addition, until this time, little study has been carried out on analog rice produced from a mixture of arrowroot starch, Glacilaria spp. extract, and spices. The novelty of this study is the production of analog rice with high levels of resistant starch and rich in antioxidants. Therefore, it can be developed as a functional food and has a good taste and aroma.

\section{Author's Contribution}

DD: Conceptualized and designed the study, elaborated the intellectual content, performed literature search, data acquisition, data analysis, statistical analysis, manuscript preparation, and manuscript revision.

RHS: Elaborated the intellectual content, performed literature search, manucript format, reviewed and revised the manuscript.

JB and ZVG: Defined the intellectual content, performed literature search, reviewed manuscript and guarantor.

DDS, RA and AT: Carried out experimental studies and reviewed manuscript.

All authors read and approved the final manuscript.

\section{Conflict of interest}

The authors have declared no conflict of interest. 


\section{References}

Adinurani, P.G. 2016. Design and analysis of agro trial data: Manual and SPSS. Plantaxia, Yogyakarta, Indonesia.

Anggraini, T., V.J. Putri, Newati and Yuliani. 2016. Characteristics of Red Sweet Potato (Ipomea batatas) analog rice (SPAR) from the addition of Cassava flour (Manihot utillisima) and Carrot (Daucus carota). Int. J. Adv. Sci. Eng. Inf. Technol., 6(5): 723-728. https://doi. org/10.18517/ijaseit.6.5.762

Aprianita, A., T. Vasiljevic, A. Bannikova and S. Kasapis. 2013. Physicochemical properties of flours and starches derived from traditional Indonesian tubers and roots. J. Food Sci. Technol., 51:3669-3679. https://doi. org/10.1007/s13197-012-0915-5

Asouri, A., R. Ataee, A.A. Ahmadi, A. Amini and M.R. Moshaei. 2013. Antioxidant and free radical scavenging activities of curcumin. Asian J. Chem., 25(13):7593-7595. https://doi. org/10.14233/ajchem.2013.15308

Astuti, R.M., Widaningrum, N. Asiah, A. Setyowati and R. Fitriawati. 2018. Effect of physical modification on granule morphology, pasting behavior, and functional properties of arrowroot (Marantha arundinacea L.) starch. Food Hydrocoll., 81: 23-30. https://doi. org/10.1016/j.foodhyd.2018.02.029

Budijanto, S. and N.D. Yuliana, 2015. Development of rice analog as a food diversification vehicle in Indonesia. J. Dev. Sustain., 10: 7-14.

Carlson, N.S. 2018. Current resources for evidence-bases practice. J. Midwifery Womens Health, 63:735-741. https://doi.org/10.1111/ jmwh.12926

Chambers, E. and K. Kadri. 2013. Associations of volatile compounds with sensory aroma and flavor: the complex nature of flavor. Molecules, 18:4887-4905. https://doi.org/10.3390/ molecules18054887

Chan, P.T. and P. Matanjun. 2017. Chemical composition and physicochemical properties of tropical red seaweed, Gracilaria changii. Food Chem., 221:302-310. https://doi. org/10.1016/j.foodchem.2016.10.066

Chan, P.T., M. Patricia, Yasir, S.M. Yasir and T.T. Song. 2014. Antioxidant activities and polyphenolics of various solvent extracts of red seaweed, Gracilaria changii. J. Appl. Phycol.,
26(6): 987-997. https://doi.org/10.1007/ s10811-013-0135-z

Damat, D. 2013. Effect of butyrylated Arrowroot starch to the digesta profile and molar ratio SCFA. J. Food Res., 2(2):44-49. https://doi. org/10.5539/jfr.v2n2p144

Damat, D., A. Tain, H. Handjani, U. Chasanah and D.D. Siskawardani. 2019a. Functional cake characteristics of modified arrowroot starch (MAS) with the gelatinizationretrograde method. IOP Conf. Ser.: Mater. Sci. Eng., 532(012017): 1-6. https://doi. org/10.1088/1757-899X/532/1/012017

Damat, D., R. Anggriani, R.H. Setyobudi and P. Soni. 2019b. Dietary fiber and antioxidant activity of gluten-free cookies with coffee cherry flour addition. Coffee Sci., 14(4):493500. https://doi.org/10.25186/cs.v14i4.1625

Damat, D., R.H. Setyobudi, J.S. Utomo, Z. Vincevica Gaile, A. Tain and D.D. Siskawardani. 2021. The characteristics and predicted of glycemic index of rice analogue from modified Arrowroot starch (Maranta arundinaceae L.). Jordan J. Biol. Sci., 14(3): 389393. https://doi.org/10.54319/jjbs/140302

Darmanto, Y.S., P.H. Riyadi and S. Susanti. 2017. Characteristic of Taro (Colocasia esculenta) and Seaweed (Eucheuma cottoni) base analogue rice frotified with fishes bone collagen (A promising anti-diabetis functional food).J. Eng. Appl. Sci., 12(12): 3055-3060.

Djaafar, T.F. and A.B. Pustika. 2010. Development of arrowroot and its processing technology to support food security. Jurnal Litbang Pertanian, 29(1):25-33.

El-Sayed, S.M. and A.M. Youssef. 2019. Potential application of herbs and spices and their effects in functional dairy products: Review article. Heliyon., 6(5) e01989:1-7. https://doi. org/10.1016/j.heliyon.2019.e01989

Francavilla, M., M. Franchi, M. Monteleone and C. Caroppo. 2013. The Red Seaweed Gracilaria gracilis as a multi products source. Mar. Drugs, 11:3754-3776. https://doi.org/10.3390/ md11103754

Fuentes-Zaragoza, E., M.J. Riquelme-Navarrete, E. Sánchez-Zapata, J.A. Pérez-Álvarez. 2010. Resistant starch as functional ingredient: A review. Food Res. Int., 43(4):931-942. https:// doi.org/10.1016/j.foodres.2010.02.004 
Garcia, M.C. and C.M.L. Franco. 2015. Effect of glycerol monostearate on the gelatinization behavior of maize starches with different amylose contents. Starch, 67: 107-116. https:// doi.org/10.1002/star.201400107

Holscher, H.D. 2017. Dietary fiber and prebiotics and the gastrointestinal microbiota. Gut Microbes, 8(2):172-184. https://doi.org/10.10 80/19490976.2017.1290756

Hur, S.J., S.Y. Lee, Y.C. Kim, I. Choi and G.B. Kim. 2014. Effect of fermentation on the antioxidant activity in plant-based foods. Food Chem., 160:346-356. https://doi.org/10.1016/j. foodchem.2014.03.112

Li, Y.O. and A.R. Komarek. 2017. Review: Dietary fibre basics: Health, nutrition, analysis, and applications. Food Qual. Saf., 1: 47-59. https:// doi.org/10.1093/fqs/fyx007

Kanatt, S.R., S.P. Chawla and A. Sharma. 2014. Antioxidant and radio-protective activities of lemon grass and star anise extracts. Food Biosci., 6:24-30. https://doi.org/10.1016/j. fbio.2014.03.002

Keyimu, X.G. 2013. The effects of using seaweed on the quality of Asian noodles. Int. J. Food Process. Technol., 4(3):1-4. https://doi. org/10.4172/2157-7110.1000216

Magallanes-Cruz, P.A, P.C. Flores-Silva and L.A. Bello-Perez. 2017. Starch structure influences its digestibility: A Review. J. Food Sci., 82(9):2016-2023. https://doi. org/10.1111/1750-3841.13809

McCleary, B.V., C. McLoughlin and L.M.J. Charmier. 2019. Measurement of available carbohydrates, digestible, and resistant starch in food ingredients and products. Cereal Chem., 00:1-24. https://doi.org/10.1002/ cche.10208

Micova, M., B. Judita, K. Ján, H. Luboš and L. Adriana.2018. Content of bioactive compounds and antioxidant activity in Garlic (Allium satioum L.). Acta Agric. Slov., 111(3):581-595. https://doi.org/10.14720/aas.2018.111.3.07

Mishra, A., H.N. Mishra and P.S. Rao. 2012. Preparation of rice analogs using extrusion technology. Int. J. Food Sci. Technol., 47(9):1789-1797. https://doi.org/10.1111/ j.1365-2621.2012.03035.x

Mnayer, D., A.S. Fabiano-Tixier, E. Petitcolas, T. Hamieh, N. Nehme, C. Ferrant, X. Fernandez and F. Chemat. 2014. Chemical composition, antibacterial and antioxidant activities of six essentials oils from the alliaceae family. Molecules, 19: 20034-20053. https://doi. org/10.3390/molecules191220034

Murray, J.C., A.M. Kiszonas, C.F. Morris. 2017. Influence of soft kernel texture on the flour, water absorption, rheology, and baking quality of durum wheat. Cereal Chem., 94(2):215-222. https://doi.org/10.1094/CCHEM-06-160163-R

Nelson, K.M., L.D. Jayme, B. Jonathan, G. James, F. G.F. Pauli and M.A. Walters. 2017. The essential medicinal chemistry of curcumin. J. Med. Chem., 60(5):1620-1637. https://doi. org/10.1021/acs.jmedchem.6b00975

Olia, P., R. Ward, B. Adhikarie and P. Torley. 2014. Parboiled rice: Understanding from a materials science approach. J. Food Eng., 124:173-183. $\quad$ https://doi.org/10.1016/j. jfoodeng.2013.09.010

Oo, K.S. and Y.Y. Than. 2019. Study on nutritional values in paddy crude and parboiled rice. Int. J. Sci. Res. Publ., 9(4):200-204. http://www.ijsrp. org/research-paper-0419.php?rp=P888450

Pathare, P., U. Opara and F. Al-Said. 2013. Colour measurement and analysis in fresh and processed foods: A review Food Bioproc Tech., 6:36-60. https://doi.org/10.1007/s11947-0120867-9

Putri, E.C.J. and S. Sumardiono. 2020. Analog rice production of composite materials flour (Cassava, Avocado seeds, and Tofu waste) for functional food. AIP Conf. Proc. 2197: 070005. https://doi.org/10.1063/1.5140938

Prajapati, V.D., P.M. Maheriya, G.K. Jani and H.K. Solanki. 2014. Carrageenan: A natural seaweed polysaccharide and its applications., Carbohydr. Polym.,105:97-112. https://doi.org/10.1016/j. carbpol.2014.01.067

Priyadarsini, K.I. 2014. The chemistry of curcumin: From extraction to a therapeutic agent. Molecules, 19:20091-20112. https://doi. org/10.3390/molecules191220091

Pudjihastuti, I., S. Sumardiono, E. Supriyo and H. Kusumayanti. 2019. Analog rice characteristics made from sago flour and arrowroot flour in supporting food diversification. AIP Conf Proc., 2114(030004):1-5. https://doi. org/10.1063/1.5112408

Pudjiastuti, A.Q. G.M.K. Arisena and A.A.K. Krisnandika. 2021. Rice import development in 
Indonesia. J. Agric. Soc. Econ., 15(2): 390-405.

Purwaningsih, J. Santoso, E. Handharyani, N.P. Setiawati and E. Deskawati. 2020. Artificial rice from Gracillaria sp. as a functional food to prevent diabetes. IOP Conf. Ser.: Earth Environ. Sci., 414 (012017): 1-7. https://doi. org/10.1088/1755-1315/414/1/012017

Puwastien, P., T.E. Siong, J. Kantasubrata, G. Craven, R.R. Feliciano and K. Judprasong (Eds.). 2011. ASEAN manual food analysis $1^{\text {st }}$ ed. Regional Centre of ASEAN Network of Food Data System Institute of Nutrition, Mahidol University Thailand.

Raghavan, S. 2007. Handbook of spices, seasonings, and flavorings. 2nd. CRC Press Taylor \& Francis Group, Boca Raton, Florida, USA. https://doi. org/10.1201/b13597

Rasyid, A., A. Ardiansyah and R. Pangestuti. 2019. Nutrient composition of dried Seaweed Gracilaria gracilis. Indonesian J. Marine Sci., 24(1):1-6. https://doi.org/10.14710/ ik.ijms.24.1.1-6

Sáez-Plaza, P. M.J. Navas, S. Wybraniec, T. Michalowski and A.G. Asuero. 2013. An overview of the Kjeldahl method of nitrogen determination. Part II. Sample preparation, working scale, instrumental finish, and quality control. Crit. Rev. Anal. Chem., 43(4): 224272. https://doi.org/10.1080/10408347.2012. 751787

Sarastuti, S., U. Ahmad and S. Sutrisno. 2019. Analysis of rice quality and application of quality assurance systems in community food business development activities. Jurnal Penelitian Pascapanen Pertanian, 15(2):63-72. https:// doi.org/10.21082/jpasca.v15n2.2018.63-72

Sepahpour, S., S. Selamat, M.Y.A. Manap, A. Khatib, A.F.A. Razis. 2018. Comparative analysis of chemical composition, antioxidant activity and quantitative characterization of some phenolic compounds in selected herbs and spices in different solvent extraction systems. Molecules, 13; 23(2):402. https://doi. org $/ 10.3390 /$ molecules 23020402

Shahidi, F. and P. Ambigaipalan. 2015. Phenolics and polyphenolics in foods, beverages, and spices: Antioxidant activity and health effects A review. J. Funct. Foods, 18:820-897. https:// doi.org/10.1016/j.jff.2015.06.018

Shirin, A.P.R. and J. Prakash. 2010. Chemical composition and antioxidant properties of ginger root (Zingiber officinale). J. Med. Plant Res., 4(24):2674-2679. https://doi. org/10.5897/JMPR09.464

Shukri, R. and Y.C. Shi, 2015. Physiochemical properties of highly cross-linked maize starches and their enzymatic digestibilities by three analytical methods. J. Cereal Sci., 63:72-80. https://doi.org/10.1016/j.jcs.2015.03.001

Stefanowicz, P. 2013. Sensory evaluation of food principles and practices, J. Wine Res., 24(1):80. https://doi.org/10.1080/09571264.2013.7646 62

Sumardiono, S., I. Pudjihastuti, A.R., Poerwoprajitno and M.S. Suswadi. 2014. Physicochemical properties of analog rice from composite flour: Cassava, Green bean, and Hanjeli. World Appl. Sci. J., 32(6):1140-1146.

Susi, L.Agustina and C. Wibowo. 2019. Digestibility in vitro of starch and protein on analog rice by formulation of Nagara Bean flour modified L. Plantarum and Sago starch with concentration of glycerol monostearate. IOP Conf. Ser. Earth Environ. Sci., 255(012012): 1-6. https:// doi.org/10.1088/1755-1315/255/1/012012

Tamura, M. and Y. Ogawa. 2012. Visualization of the coated layer at the surface of rice grain cooked with varying amounts of the cooking water. J. Cereal Sci., 56:404-409. https://doi. org/10.1016/j.jcs.2012.06.002

Valdez-Morales, M., L.G. Espinosa-Alonso, L.C. Espinoza-Torres, F. Delgado-Vargas and S. Medina-Godoy. 2014. Phenolic content and antioxidant and antimutagenic activities in tomato peel, seeds, and byproducts. J. Agric. Food Chem., 62(23): 5281-5289. https://doi. org/10.1021/jf5012374

Vallverdú-QueraltJorge, A., J. Regueiro, J.F.R. Alvarenga, M. Martinez-Huelamo, L.N. Leal and R.M. Lamuela-Raventos. 2015. Characterization of the phenolic and antioxidant profiles of selected culinary herbs and spices: Caraway, Turmeric, Dill, Marjoram and Nutmeg., Food Sci. Technol., 35(1):189195. https://doi.org/10.1590/1678-457X.6580

Wada, T., T. Umemoto, N. Aoki, M. Tsubone, T. Ogata and M. Kondo. 2010. Starch eluted from polished rice during soaking in hot water is related to the eating quality of cooked rice. J. Appl. Glycosci., 58:13-18. https://doi. org/10.5458/jag.jag.JAG-2010_009 
Wahjuningsih, S.B., Haslina, S. Untari and A. Wijanarka. 2018. Hypoglycemic effect of analog rice made from modified Cassava flour (Mocaf), Arrowroot flour, and Kidney bean flour on STZ-NA induced diabetic rats. Asia Pac. J. Clin. Nutr., 10:8-15. https://doi. org/10.3923/ajen.2018.8.15

Wahjuningsih, S.B. and S. Susanti. 2018. Chemical, physical, and sensory characteristics of analog rice developed from the Mocaf, Arrowroof, and Red bean flour. IOP Conf. Ser. Earth Environ. Sci., 102(012015): 1-10. https://doi. org/10.1088/1755-1315/102/1/012015

Wahjuningsih, S.B., Y Marsono, D. Praseptiangga, B. Haryanto and M.N. Azkia. 2020. Organoleptic, chemical, and physical characteristics of Sago (Metroxylon spp.) analog rice supplemented with Red bean (Phaseolus vulgaris) flour as a functional food. Int. J. Adv. Sci. Eng. Inf. Technol., 10(3): 1289-1296. https://doi. org/10.18517/ijaseit.10.3.11098

William, H. and G.W. Latimer. 2019. Official methods of analysis of AOAC International. 21st ed. Rockville, Md AOAC International, USA.

Yang, Z., X. Han, H. Wu, L. Zhang, L. Zhang and M.J. Iqbal. 2017. Impact of emulsifiers addition on the retrogradation of rice gels during lowtemperature storage. J. Food Qual., 4247132: 1-7. https://doi.org/10.1155/2017/4247132

Yousf, N., F. Nazir, R. Salim, H. Ahsan and A. Sirwal. 2017. Water solubility index and water absorption index of extruded product from rice and Carrot blend. J. Pharmacogn. Phytochem., 6(6):2165-2168. 